\title{
Clinical appearance of oral mucous in children with B-major thalassemia
}

\author{
Areta Tera Lova*), Eka Chemiawan*, Tenny Setiany Dewi** \\ *Department of Pedodontics Faculty of Dentistry Universitas Padjadjaran, Bandung \\ **Department of Oral Medicine Faculty of Dentistry Universitas Padjadjaran, Bandung
}

\begin{abstract}
Beta major thalassemia is characterized by severe hereditary hemolytic anemia. The oral mucous of children with beta major thalassemia becomes yellow grayish due to the combination of pallor, icterus/yellowish and grayish pigmentation. The purpose of this research was to obtain a clinical data of oral mucous color of beta major thalassemia childrens patients at the Thalassemia Polyclinic of Pediatric Department in Dr. Hasan Sadikin General Hospital Bandung in December 2009 until January 2010. This research was the description method with survey technique. The sampling technique was consecutive sampling. Sample was collected in one month and resulting 129 sample. The data obtained by clinical evaluation of each part of oral mucous. Research result showed that the clinical colour of oral mucous of beta major thalassemia childrens patiens becomes pallor, yellowish, yellow, yellow grayish, yellow blackish differently of each part of oral mucous. Pallor mostly at tongue, yellowish at bucal mucous, yellow at soft palate, yellow grayish at sublingual, hard palate, gingival, and yellow blackish at hard palate. The conclusion of this research were that the color of the oral mucous beta major thalassemia childrens patiens was changes and was different with color of oral mucous in normal children.
\end{abstract}

Key words: Beta major thalassaemia, color of oral mucous

\section{ABSTRAK}

Thalassemia beta mayor adalah penyakit anemia hemolitik yang diturunkan secara genetik. Pada anak penderita thalassemia beta mayor terjadi perubahan warna mukosa mulut secara klinis menjadi kuning keabuan yang merupakan kombinasi antara pucat, ikterus/kekuningan dan pigmentasi keabuan. Tujuan penelitian ini adalah untuk mendapatkan data mengenai gambaran klinis warna mukosa mulut pada anak penderita thalassemia beta mayor di poliklinik Thalassemia Bagian Ilmu Kesehatan Anak RSUP Dr. Hasan Sadikin Bandung. Penelitian ini menggunakan metode deskriptif dengan teknik survei. Pengambilan sampel secara consecutive sampling dalam waktu 1 bulan dan diperoleh 129 sampel. Data diperoleh dengan cara melakukan pemeriksaan klinis pada setiap bagian mukosa mulut. Hasil penelitian menunjukkan bahwa terjadi beberapa perubahan warna mukosa mulut pada anak penderita thalassemia beta mayor menjadi pucat, pucat kekuningan, kuning, kuning keabuan dan kuning kehitaman yang berbeda pada setiap lokasi. Warna pucat terutama terdapat pada lidah, warna pucat kekuningan pada mukosa bukal, warna kuning pada palatum molle, warna kuning keabuan pada dasar mulut, palatum

\footnotetext{
*) Correspondence author: Areta Tera Lova, Department of Pedodontic Faculty of Dentistry Universitas Padjadjaran
} Jl. Sekeloa Selatan No. 1 Bandung, West Java-Indonesia, Tel./Fax: +6222-2504985/2532805 
durum dan gingiva, warna kuning kehitaman pada palatum durum. Kesimpulan dari penelitian ini adalah menunjukkan terjadi perubahan warna mukosa mulut secara klinis yang berbeda pada anak penderita thalassemia beta mayor dibandingkan dengan warna mukosa mulut yang normal.

Kata kunci: Thalassemia beta mayor, warna mukosa mulut

\section{INTRODUCTION}

Thalassemia is a hereditary disease in hemoglobin synthesis caused by reduced synthesis of one or more globin chains. This abnormality characterized with impaired alpha or beta chain synthesis from globin that could be either heterozygous or homozygous. Thalassemia occured as a result of unbalanced globin chain in hemoglobin because of reduced alpha or beta synthesis. Reduction or deletion of one or more globin chains would impair the balance system, as a result there would be small amount of hemoglobin formed in red blood cell. Based on the impairment of globin chain synthesis, thalassemia can be divided into two groups which is alpha (a) thalassemia, characterized by impairment of alpha chain synthesis and beta $(B)$ thalassemia, characterized by impairment of beta chain synthesis. Based on the amount of impaired globin chain synthesis, thalassemia could be divided into (alpha or beta) major thalassemia and (alpha or beta) minor thalassemia.

Oral mucous is an epithelial lining that covered the oral cavity and well known as oral mucous. Epithelial lining of the oral mucous is a layered flat epithelium. In normal condition, the oral mucous clinically would appear pink with red color under the mucous with more vascularization, this could be seen in labial mucous, buccal mucous, floor of the mouth, tongue, hard palate, soft palate and gingiva.

The color of oral mucous can be changed as a result of a disease, for instance in a blood disorder such as beta-major thalassemia. Betamajor thalassemia is a haemolytic anemia disorder with hereditary trait and inherited by recessive autosomal. Based on the epidemiological data, geographic distribution of beta-major thalassemia mainly found in Mediterania, Middle East, India, Pakistan and Asia countries. Beta-major thalassemia prevalence in Italia is $10 \%$, Greece 5 -
$10 \%$, China $2 \%$, India $1-5 \%$, Africa $1 \%$, and Southeast Asia $5 \%$ including Indonesia as much as $3 \%$, while in figure of world map then it would form as if it is a belt (thalassemic belt).

Beta-major thalassemia caused by reduced beta polypeptide chain synthesis that constitute the globin molecule in hemoglobin. Beta-major thalassemia also known as Cooley's anemia, Mediteranian anemia, Erythroblastic anemia or Leptocytosis hereditary which is a type of thalassemia that was characterized by a heavy clinical symptoms. This symptoms appeared as early years of life. Neonates with beta-major thalassemia did not show the symptoms of thalassemia at newborn, but there would be anemia in the early period of life and getting worse as the neonates would need continued blood transfusion.

General clinical symptoms clearly visible as the neonates reached 1 year old or less. Physical and weight development were lower than normal healthy children with similar age. Enlarged lymph or splenomegaly could eventually decreased platelets and leukocyte below normal, so that children with beta-major thalassemia susceptible toward bleeding and infection. Hemostatic disorder occured as a result of decreased liver function. In the older children, showed a face well known as facies Cooley (mongoloid face) with Class II type 1 malocclusion from Angle classification, this condition caused by impaired face bone and skull development.

There are also skeletal changes in betamajor thalassemia children which could be clearly visible than another types of thalassemia. Radiograph examination in skeletal structure showed changes, as seen on the skull and alveolar bone. There is a thickening medulla layer, inside and outside thinning of cortical bone, the trabeculae between the cortical bones elongated that create an image on skull bone surface also known as "hair-on-end". Depletion of the lamina dura and circular radioluscent in the alveolar bone 
also visible in radiograph examination.

In laboratory examination children with beta major thalassemia showed a decrease in hemoglobin, hematocrit, red blood cell and leukocyte count. The unconjugated bilirubin and reticulocyte levels elevated as a result of haemolytic anemia. Diagnostic decision for beta-major thalassemia can be made by considering these two conditions prenatal and postnatal. Prenatal diagnosis would be made by examining the mother of fetus such as complete peripheral blood checking and hemoglobin electrophoresis. Postnatal diagnosis of beta-major thalassemia can be made by familial history, clinical examination, peripheral blood smear examination and hemoglobin electrophoresis examination. The prognosis of beta-major thalassemia in children that do not undergo an effective long term treatment would cause a death before 8 years old. Death could also be caused by decompensated heart (decompensatio cordis), hepar disfunction or infection. The prognosis of beta-major thalassemia children also depend on the children conformity to a long term treatment which is continued blood tansfusion, iron bonding therapy, and vitamin supplement. Splenectomy and bone marrow transplant can be done as a definitive therapy, then the prognosis will be better for children with beta-major thalassemia.

For children with beta-major thalassemia that experienced haemolytic anemia from their early period of life. Haemolytic anemia is an anemia caused by erytrocyte depletion in blood vessel before its time (erytrocyte normal life span is \pm 120 days). Haemolysis occured will cause a decrease in hemoglobin level, increased bilirubin level and the need of blood transfusion as a result of hypoxia.

Decreased level of hemoglobin will eventually change the color of oral mucous becoming pale. This condition occured if hemoglobin level was lower than $10 \mathrm{~g} / \mathrm{dL}$. The shorter life span of erytrocyte which is less than 120 days will eventually increased the result of erytrocyte depletion that is the unconjugated bilirubin in blood up to 2-3 $\mathrm{mg} / \mathrm{dL}$ therefore hyperbilirubinemia occured and clinical symptoms such as icterus/yellow in oral mucous. Continued blood transfusion will be needed in order to maintain the hemoglobin level, but there is an adverse effect of this such as accumulation of iron excessively inside the tissues that will cause haemosiderosis with clinical symptoms of greyish pigmentation in the oral mucous. Decreased level of hemoglobin, increased level of bilirubin and continued blood transfusion will eventually caused change in oral mucous color into greyish yellow which is a combination of pale, icterus/yellow and greyish pigmentation of hemosiderosis process. To be questioned is how will the description of clinically oral mucous color be in beta-major thalassemia children? This study objectives are to obtain data, description and information of earlier studies toward beta-major thalassemia children.

\section{METHODS}

This study was a descriptive research with survey technique. The population of this study was all the children with beta-major thalassemia hospitalized in Thalassemia Polyclinic, Pediatric Department of RSUP Dr. Hasan Sadikin Bandung. The sample was taken out of the population by consecutive sampling, which means every patient with beta-major thalassemia that meet the criterias would be included into the study in a particular time period, hopefully to meet the sample size.

The criterias were boys and girls aged 214 years suffering beta-major thalassemia and hospitalized in Thalassemia Polyclinic, Pediatric Department of RSUP Dr. Hasan Sadikin Bandung. Willing to be examined and informed consent from their parents.

This study started from 16 December 2009 until 15 January 2010 with sample size 129 children. The procedure of this study was: patient put on their cistern dribble cloth and then gargled with pure water. Patient asked to open their mouth, and then examiner examined thoroughly using the mouth mirror and flashlight to find out the color of oral mucous in an order of labial, buccal, floor of the mouth, tongue, hard palate, soft palate and gingiva. Subsequently, patient asked to wash their mouth again. The results were documented and noted in the examination form. Figures and data obtained, collected and analyzed by the end of the study and then presented as figures, diagrams and tables. 


\section{RESULTS}

The sample characterized based on their oral mucous color on every clinically observed locations started from the labial mucous, buccal mucous, floor of the mouth, tongue, hard palate, soft palate, and gingiva as showed in Table 1 to 6 as follows: Table 1 showed the color changes on labial mucous of children with beta-major thalassemia. As much as 84 children $(65.12 \%)$ with pale labial mucous predominantly showed while 2 patients $(1.55 \%)$ with greyish yellow labial mucous were the least of this characteristic.

Table 2 showed the color changes on buccal mucous of patients with beta-major thalassemia. As much as 73 patients $(56.59 \%)$ predominantly showed pale yellow while 2 patients $(1.55 \%)$ showed greyish yellow were the least of this char-

Table 1. Sample distribution based on color change on labial mucous

\begin{tabular}{lcc}
\hline \multicolumn{1}{c}{ Color change in labial mucous } & Total & $\%$ \\
\hline Pale & 84 & 65.12 \\
Pale yellow & 43 & 33.33 \\
Yellow & 0 & 0 \\
Greyish Yellow & 2 & 1.55 \\
Dark yellow & 0 & 0 \\
\hline Total & 129 & 100 \\
\hline
\end{tabular}

Table 2. Sample distribution based on color change on buccal mucous

\begin{tabular}{lcc}
\hline Color change in buccal mucous & Total & $\%$ \\
\hline Pale & 54 & 41.86 \\
Pale yellow & 73 & 59.69 \\
Yellow & 0 & 0 \\
Greyish Yellow & 2 & 1.55 \\
Dark yellow & 0 & 0 \\
\hline Total & 129 & 100 \\
\hline
\end{tabular}

Table 3. Sample distribution based on color change on floor of the mouth

\begin{tabular}{lcc}
\hline Color change in floor of the mouth & Total & $\%$ \\
\hline Pale & 0 & 0 \\
Pale yellow & 10 & 7.75 \\
Yellow & 1 & 0.77 \\
Greyish Yellow & 110 & 85.28 \\
Dark yellow & 8 & 6.20 \\
\hline Total & 129 & 100 \\
\hline
\end{tabular}

acteristic. Table 3 showed the color changes on the floor of the mouth of patients with beta-major thalassemia. As much as 110 patients $(85.28 \%)$ with greyish yellow floor of the mouth were the dominant sample of this characteristic, while 1 patient $(0.77 \%)$ with yellow floor of the mouth was the lowest accounted sample of this characteristic.

Table 4 showed the color changes on the tongue of children with beta-major thalassemia. As much as 122 patients (94.57\%) with pale color of tongue mucous predominantly showed in this characteristic while 7 patients $(5.43 \%)$ with pale yellow tongue mucous were the least of this table. Table 5 showed color changes on the hard palate of children with beta-major thalassemia. As much as 110 patients (85.28\%) with greyish yellow hard palate were the most dominant sample of this characteristic while only 19 chil-

Table 4. Sample distribution based on color change on the tongue

\begin{tabular}{lcc}
\hline \multicolumn{1}{c}{ Color change in tongue } & Total & $\%$ \\
\hline Pale & 122 & 94.57 \\
Pale yellow & 7 & 5.43 \\
Yellow & 0 & 0 \\
Greyish Yellow & 0 & 0 \\
Dark yellow & 0 & 0 \\
\hline Total & 129 & 100 \\
\hline
\end{tabular}

Table 5. Sample distribution based on color change on hard palate

\begin{tabular}{lcc}
\hline \multicolumn{1}{c}{ Color change in hard palate } & Total & $\%$ \\
\hline Pale & 0 & 0 \\
Pale yellow & 0 & 0 \\
Yellow & 0 & 0 \\
Greyish Yellow & 110 & 85.28 \\
Dark yellow & 19 & 14.72 \\
\hline Total & 129 & 100 \\
\hline
\end{tabular}

Table 6. Sample distribution based on their color change on soft palate

\begin{tabular}{lcc}
\hline \multicolumn{1}{c}{ Color change on soft palate } & Total & $\%$ \\
\hline Pale & 0 & 0 \\
Pale yellow & 0 & 0 \\
Yellow & 60 & 46.51 \\
Greyish Yellow & 57 & 44.19 \\
Dark yellow & 12 & 9.30 \\
\hline Total & 129 & 100 \\
\hline
\end{tabular}


Table 7. Sample distribution based on their color change of gingiva

\begin{tabular}{lcc}
\hline \multicolumn{1}{c}{ Color change on gingiva } & Total & $\%$ \\
\hline Pale & 29 & 22.48 \\
Pale yellow & 37 & 28,69 \\
Yelloow & 0 & 0 \\
Greyish Yellow & 62 & 48.06 \\
Dark Yellow & 1 & 0.77 \\
\hline Total & 129 & 100 \\
\hline
\end{tabular}

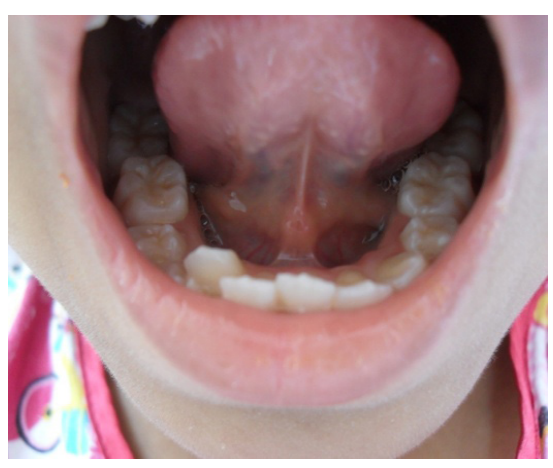

Figure 1. Greyish yellow coloration on the floor of the mouth of a child with Beta-Major Thalassemia.

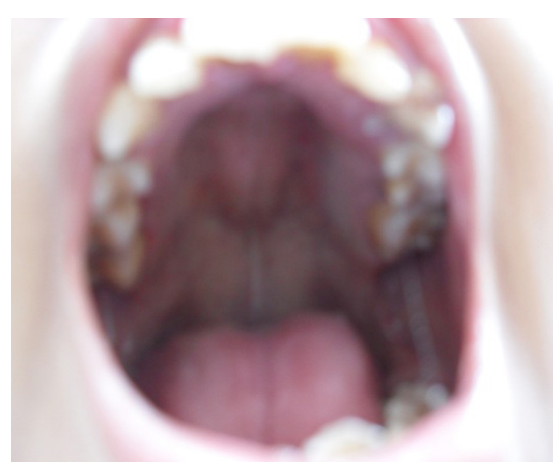

Figure 2. Greyish yellow coloration on the hard palate of a child with Beta-Major Thalassemia.

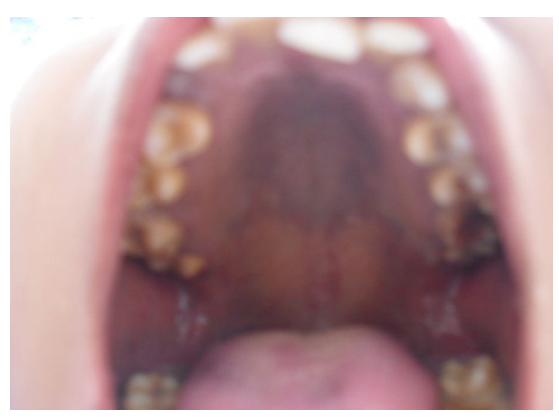

Figure 3. Yellow coloration on the soft palate of children with Beta-Major Thalassemia.

dren $(14.72 \%)$ with dark yellow hard palate were the infrequently showed on this characteristic.
Table 6 showed that there were the changes on the soft palate of children with beta-major thalassemia. As much as 60 patients $(46.51 \%)$ with yellow soft palate were the dominant sample of this characteristic while 12 patients $(9.30 \%)$ with dark yellow soft palate were the least group of this characteristic.

Table 7 showed color changes on the gingiva of children with beta major thalassemia. As much as 62 children (48.06\%) with greyish yellow gingiva were the most sample of this characteristic while only 1 patient $(0.77 \%)$ with dark yellow gingiva were the least sample of this characteristic.

Based on this study results of color changes on the oral mucous of children with beta-major thalassemia the resume will depicted as Diagram 1.

\section{DISCUSSION}

Beta-major thalassemia is an anemia haemolytic disease with hereditary trait, inherited as recessive autosomal. Children with beta major thalassemia would appeared normal at birth, but suffered from blood insufficiency at the age 3-18 months. These children would need a continued blood transfusion for life time. Survival rate of children with beta major thalassemia would be depended on the patient obedience in their long term treatment, such as continued blood transfusion, iron bonding therapy and vitamin supplements. Splenectomy therapy and bone marrow transplantation could be done as a definitive therapy, then the prognosis of the patient with betamajor thalassemia would be better. If the children with beta-major thalassemia did not obey the long term therapy, then the life span would be around 1-8 years.

Haemolysis is a process of erytrocyte breakdown inside the vessels before its time (before average life span of erytrocyte around \pm 120 days). Haemolysis process would reduce the hemoglobin level to below $2 \mathrm{~g} / \mathrm{dL}$ in a week period. General symptoms of anemia such as pale oral mucous would be observed in $\mathrm{Hb}$ level lower than $10 \mathrm{~g} /$ $\mathrm{dL}$. The more severe and faster the hemoglobin level decrease the more severe the symptoms appeared.

Increasing erytrocyte breakdown would cause an increased unconjugated bilirubin produc- 


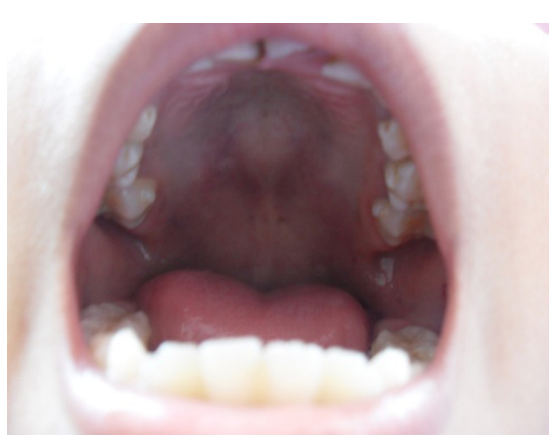

Figure 4. Greyish yellow coloration on the soft palate of children with Beta-Major Thalassemia.

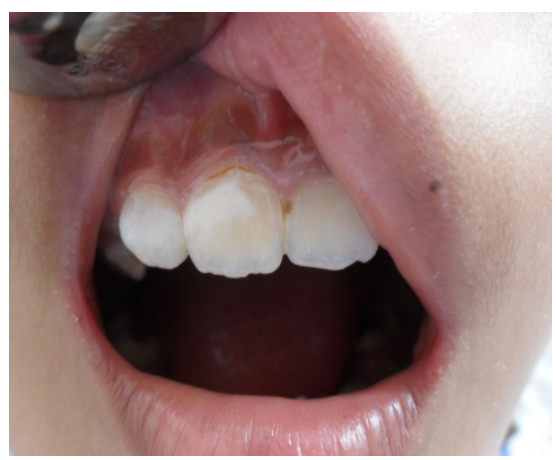

Figure 5. Greyish yellow coloration on gingiva of a child with Beta-Major Thalassemia.

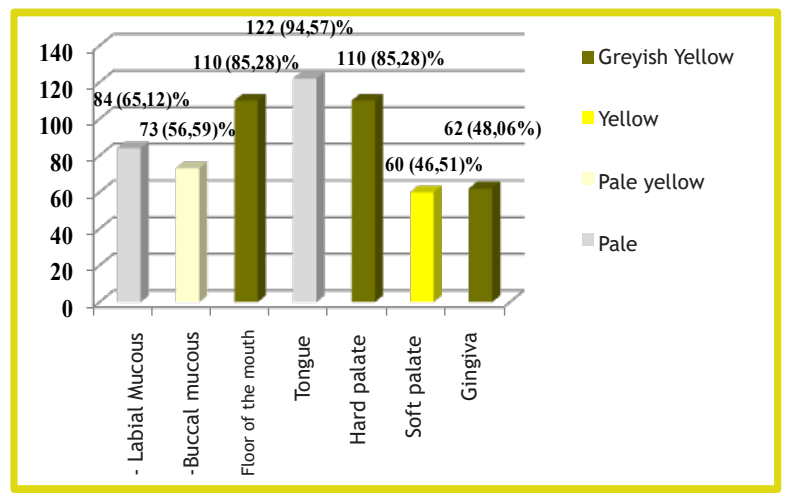

Diagram 1. Clinical appearance of oral mucous color of children with Beta-Major Thalassemia.

tion which did not soluble in fat. Clinical symptoms appeared would be icteric/yellow on the skin an oral mucous of children with beta-major thalassemia. Icteric appearance would be clinically obvious in serum bilirubin level which up to 2-3 mg/dL (normal: 0.1-0.8 mg/dL).

Long term blood transfusion would be needed in order to overcome the decreased hemoglobin level and maintain the $\mathrm{Hb}$ level $\geq 10 \mathrm{~g} / \mathrm{dL}$. Blood transfusion dose of $15-20 \mathrm{mg} / \mathrm{kg}$ packed red cell (PRC) would be applied 4-5 times a week. Adverse effects occured from long term blood transfusion would be hemosiderosis which is an iron level increase inside the tissue with clinical symptoms would be a greyish pigmentation.

Oral mucous color of children with betamajor thalassemia as a result would be changed into greyish yellow in combination with pale, icteric/yellow and greyish pigmentation from hemosiderosis, also showed in children patients with beta-major thalassemia in Thalassemia Polyclinic, Pediatric Department of RSUP (Gorvernment Hospital) Dr. Hasan Sadikin Bandung that had been observed as sample of this study.

Excessive erytrocyte destruction as a result of haemolytic anemia, cause a decreased hemoglobin level. Hemoglobin level in children below normal $10 \mathrm{~g} / \mathrm{dL}$ cause a hypoxia condition as a result of hemoglobin function to distribute oxygen into tissues disrupted so that pale appearance occured. Based on the result of this study it showed that children with beta-major thalassemia hemoglobin level at the time of first examination as much as 92 children $(71.31 \%)$ had hemoglobin level around $7-10 \mathrm{~g} / \mathrm{dL}$ and 37 children $(28,69 \%)$ had hemoglobin level less than $7 \mathrm{~g} / \mathrm{dL}$. This would clinically appeared on the tongue in as much as 122 children (94.57\%) and labial mucous in 84 children $(65.12 \%)$ with beta-major thalassemia.

Haemolysis occured in erytrocyte would cause an increased production of unconjugated bilirubin that did not soluble in fat/lipid of hemoglobin. An increased of this bilirubin level would appeared clinically as an icteric/yellow if the bilirubin level were around $2-3 \mathrm{mg} / \mathrm{dL}$ or more. Based on this study it showed that oral mucous color change in children with beta-major thalassemia become pale yellow on buccal mucous as much as 73 children (56.69\%) and yellow on soft palate for as much as 60 children (46.51\%). Histological structure of the soft palate contained much more lipid/fat tissues so that unconjugated bilirubin soluble in fat/lipid deposited would appear yellow soft palate, if compared to buccal mucous which was pale yellow.

In children with beta-major thalassemia that had had blood transfusion will experience hemosiderosis. Hemosiderosis occured as the blood transfusion with a dose of $15-20 \mathrm{ml} / \mathrm{kg}$ every $4-5$ 
weeks, which could not be avoided because every $500 \mathrm{ml}$ carries around $200 \mathrm{mg}$ of iron into organ tissues that could not be excreted physiologically. Based on the study about 47 children (36.43\%) with beta-major thalassemia had packed red cell (PRC) blood transfusion once in 1 to 2 weeks at a dose of $170-350 \mathrm{ml}$ and as much as 77 patients (56.69\%) inititated blood transfusion at the age of less than 1 year. Clinical symptoms observed were greyish yellow pigmentation on the floor of the mouth in 110 children $(85.28 \%)$, hard palate in 110 children $(85.28 \%)$ and gingiva in 62 children (48.06\%). Mucous color changes into greyish yellow also observed on the floor of the mouth, hard palate and gingiva which were combination of pale, icterus/yellow, and greyish pigmentation as a result from heomosiderosis (Ashen gray). Greyish color changes were caused by an extended vascularization below the oral mucous of floor of the mouth and hard palate so that excessive Fe (iron) deposition would easily appeared. The gingiva structure also similar with the hard palate in thickness, epithelial keratinization and density so that its color change was similar with the hard palate.

\section{CONCLUSION}

Based on this study and statistical anlysis, then it can be concluded that color changes on the children oral mucous with beta-major thalassemia into pale, yellowish pale, yellow, greyish yellow, and dark yellow which were different on each location. The pale color particularly on the tongue, yellowish pale on the buccal mucous, yellow on the soft palate, greyish yellow on the floor of the mouth, hard palate and gingiva, dark yellow on the hard palate.

\section{REFERENCES}

1. Nussbaum RL, Mc. Innes $R$, Willard $H$. Thompson \& Thompson genetics in medicine. $6^{\text {th }}$ ed. Philadelphia: W.B. Saunders Co.; 2001. p. 193.

2. Welbury RR. Paediatric dentistry. $3^{\text {rd }}$ ed. New York: Oxford University Press Inc.; 2005. p. 381, 399.

3. Mc Phee S, Papadakis MA. Medical diagnosis and treatment. $46^{\text {th }}$ ed. New York: Mc. Graw Hill Medical; 2007. p. 496-7.

4. Kumar V, Abbas AK, Fausto N, Robbins SL, Cotran RZ. Robbins and Cotran pathologic basis of disease. $7^{\text {th }}$ ed. Philadelphia: Elsevier Saunders; 2005. p. 432, 632-4.

5. Harty FJ, Ogston R. Kamus kedokteran gigi. Jakarta: EGC; 1995. p. 204.

6. Langlais RP, Miller CS. Color atlas of common oral disesase. $3^{\text {th }}$ ed. Philadelphia: Lippincott Co.; 2003. p. 2.

7. Bakta IM. Hematologi klinik ringkas. Jakarta: EGC; 2006. p. 12, 16-8, 50, 56, 58, 89-91, 94-5.

8. Rajendran R, Sivapathasundharam B. Textbook of oral pathology. $5^{\text {th }}$ ed. New Delhi: Elsevier India Private Ltd.; 2006. p. 1048-9.

9. Leavell BS, Thorup OA. Fundamentals of clinical hematology. Philadelphia: W.B. Saunders Co.; 1987. p. 178.

10. Weatherall DJ. The thalassemias. In: Beutler E, editor. Williams hematology. $5^{\text {th }}$ ed. New York: Mc Graw Hill. 1995. p. 581-3, 600-1.

11. Pinkham JR, Casamassimo PS, Fields Jr. HW Denis J. Pediatric dentistry-infancy through adolesence. $4^{\text {th }}$ ed. St. Louis: Elsevier Saunders; 2005. p. 78.

12. Sapp JP, Eversole LR, George W, Wysocki. Contemporary oral and maxillofacial pathology. $2^{\text {nd }}$ ed. China: Mosby; 2004. p. 397.

13. Yayasan Thalassemia Indonesia. Thalassemia, apakah itu, mengapa terjadi, dan bagaimana mencegahnya. Jakarta: PT. Bumi Prakarsa Cipta; 1987. p. 2, 10, 22-3.

14. Bricker SL, Langlais RP, Miller CS. Oral diagnosis, oral medicine, and treatment planning. $2^{\text {nd }}$ ed. Philadelphia: A. Waverly Co.; 1994. p. 375.

15. Catzel P, Robert I. Kapita selekta pediatri. Jakarta: EGC; 1995. p. 127, 130.

16. Supandiman I. Hematologi klinik. Bandung: PT Alumni; 1997. p. 39, 50, 68.

17. Nelson WE, Behrmann RE. Ilmu kesehatan anak. $15^{\text {th }}$ ed. Jakarta: EGC; 2000. p. 1709-11, 1387.

18. Greenberg MS, Glick M. Burket's oral medicine diagnosis and treatment. $10^{\text {th }}$ ed. Spanyol: BC Decker Inc.; 2003. p. 435.

19. Sudjana. Metode statistika. $6^{\text {th }}$ ed. Bandung: Tarsito; 2002. p. 168-9. 
20. Lynch MA, Brightman VJ, Greenberg MS. Burkett's oral medicine, diagnosis and treatment. $9^{\text {th }}$ ed. Philadelphia: J.B. Lippincott Co.; 1994. p. 533.
21. Merenstein GB, Merenstein DW, Kaplan AA. Buku pegangan pediatri (Handbook of pediatrics). $17^{\text {th }}$ ed. Jakarta: Widya Medika; 2001. p. $161,617$. 